\title{
CT Sectional and Macroscopic Examinations of the Hip Joint Structure in the Carcass of an Adult and a Fetus Orang-Utan
}

\author{
Hideki ENDO ${ }^{1)}$, Koichiro YOSHIHARA ${ }^{2)}$, Misato KASEDA ${ }^{3)}$, \\ Takeo SAKAI ${ }^{4)}$, Takuya ITOU ${ }^{4)}$, Hiroshi KOIE ${ }^{5)}$ and Junpei KIMURA ${ }^{6)}$
}

1) Department of Zoology, National Science Museum, Tokyo, 3-23-1 Hyakunin-cho, Shinjuku-ku, Tokyo 169-0073

2) Tama Zoological Park, Tokyo 191-0042

3) Department of Veterinary Anatomy I, Azabu University School of Veterinary Medicine, Kanagawa 229-8501

4) Department of Preventive Veterinary Medicine and Animal Health

5) Laboratory of Comprehensive Veterinary Clinical Studies

6) Department of Veterinary Anatomy, College of Bioresource Sciences, Nihon University, Kanagawa 252-8510, Japan (2004.1.2 受付, 2004.3 .3 受理)

\section{オランウータンの成獣と胎子の死体を用いた股関節構造の CT 像観察と肉眼解剖学的検討}

\author{
遠藤秀紀 ${ }^{1)}$, 吉原耕一郎 ${ }^{2)}$, 加世多美怜 ${ }^{3)}$, 酒井健夫 ${ }^{4)}$, 伊藤琢也 ${ }^{4)}$, 鯉江 洋 $^{5)}$, 木村順平 ${ }^{6)}$ \\ 1）国立科学博物館動物研究部 干 169-0073 新宿区百人町 3-23-1 \\ 2）東京都多摩動物公園 干 191-0042 日野市程久保 7-3-1
}

3）麻布大学獣医学部解剖学第一研究室 $=229-8501$ 相模原市淵野辺 1-17-71

4）日本大学生物資源科学部獣医衛生学教室

5) 同総合臨床獣医学研究空

6）同獣医解剖学教室 $=252-8510$ 藤沢市亀井野 1866

\begin{abstract}
Using the non-destructive CT section methods, the hip joint was observed in an adult carcass and late stage fetus of the orang-utan. The macroscopic dissection was also carried out in an adult carcass. The CT images pointed out that the late stage fetus did not possess the ligament of head of femur as well as in the adult. The ligament completely disappeared at least in the late stage fetus of the orang-utan. From the macroscopic observation in the adult, the two thick parts of the iliofemoral ligament, the thin pubofemoral ligament, and the well-developed ischiofemoral ligament were confirmed, however the ligament of head of femur was not also detected between the acetabulum and the head of the femur as described in some former studies. The CT images helped us to confirm the structure of the hip joint as a non-destructive method.
\end{abstract}

Key words : CT, hip joint, orang-utan.

Jpn. J. Zoo Wildl.Med. 9(2) : 119-123, 2004

The hip bone and the head of femur is not strongly connected in the hip joint in the orang-utan (Pongo pygmaeus). It has been known that the orang-utan does not possess the ligament of head of femur from some preliminary observations [1, 2]. Although the reason why the orang-utan need not functionally the ligament structure connecting the head of femur and the acetabulum has remained unclear, it has been thought that the ligament of head of femur was lost in the transitional stage from its ancestor to the living orang-utan. So, we have expected that the connecting mechanism of the hip joint should be detailed in this species, and the developmental examinations would be undertaken in the fetus to clarify the process in which the ligament of head of femur disappears from the hip joint. Since the adult and the late stage fetus of the orang-utan had been donated to us from the zoo, only adult carcasses were dissected and the hip joint was observed by naked eyes. Since the fetus of the orang-utan is rare, we should store its intact dead body as museum specimen. For this purpose we applied CT (computed tomography) techniques for the dead bodies to observe the hip joint by non-destructive method in the fetus as well as in the adult.

The two dead bodies of the adult orang-utan have been donated to the National Science Museum, Tokyo, by Tama Zoological Garden (Tokyo, Japan) (Table 1). One of the two 
Hideki ENDO et al.

Table. 1. Materials of the orang-utan used in this study

\begin{tabular}{cccccc}
\hline Sex & Age & Origin & Date of death & Cause of death & Skeleton Specimen No. \\
\hline $\begin{array}{c}\text { Adult } \\
\text { female }\end{array}$ & 19 years & Tama Zoological Park & 2003 Feb.13 & pneumonia & - \\
female & 33 years & Tama Zoological Park & 2001 Dec. 4 & stillbirth & NSMT-M33042 \\
$\begin{array}{c}\text { Fetus } \\
\text { female }\end{array}$ & - & Tama Zoological Park & 2003 Feb.13 & unknown & - \\
\hline
\end{tabular}

dead bodies included a dead late stage fetus and died just before the birth. While we dissected these two carcasses to macroscopically observe the hip joint area, the CT scanning method was applied for an adult and a fetus to elucidate the connecting structure between the head of the femur and the hip bone by the non-destructive observation, so that the rare carcass could be maintained as intact specimen in the museum. The hip joint area was serially sectioned by CT (CT-W450-10A: Hitachi Medical Corporation, Japan).

The connecting structure between the femur and the hip bone consisted of the iliofemoral, pubofemoral and ischiofemoral ligaments in the extracapsular regions (Figs. 1 and 2). The iliofemoral ligament represented the lateral and medial parts. Both parts were strong and broad, and ran from the cranial area of the acetabulum to the neck of femur (Fig. 1). Especially the lateral part reached the intertrochanteric line. The pubofemoral ligament arose from the ventro-lateral par of the pubis to insert to the caudal surface in the neck of the femur (Fig. 2). The ligament was weak and narrow, however sent the distinctive collagen bundles to the femur. In contrast, the ischiofemoral ligament was thick and strong (Fig. 3). It formed a single and long slip from the latero-cranial part of the ischium close to the acetabulum to the neck of the femur and the acetabular labrum.

After cutting of both parts of the iliofemoral ligament, the head of the femur was easily dislocated from the acetabulum (Fig. 2). Certainly we confirmed the acetabular fossa that was filled with the connective tissues, however, the ligament of head of femur was not present between the head and the acetabular fossa. A series of the transverse CT sections shows the hip joint (Fig. 3). The head of the femur was articulated to the shallow acetabulum. The acetabular fossa could be also confirmed in the CT sections, however, any soft part connecting the acetabulum with the femur was not observed in the intracapsular space.
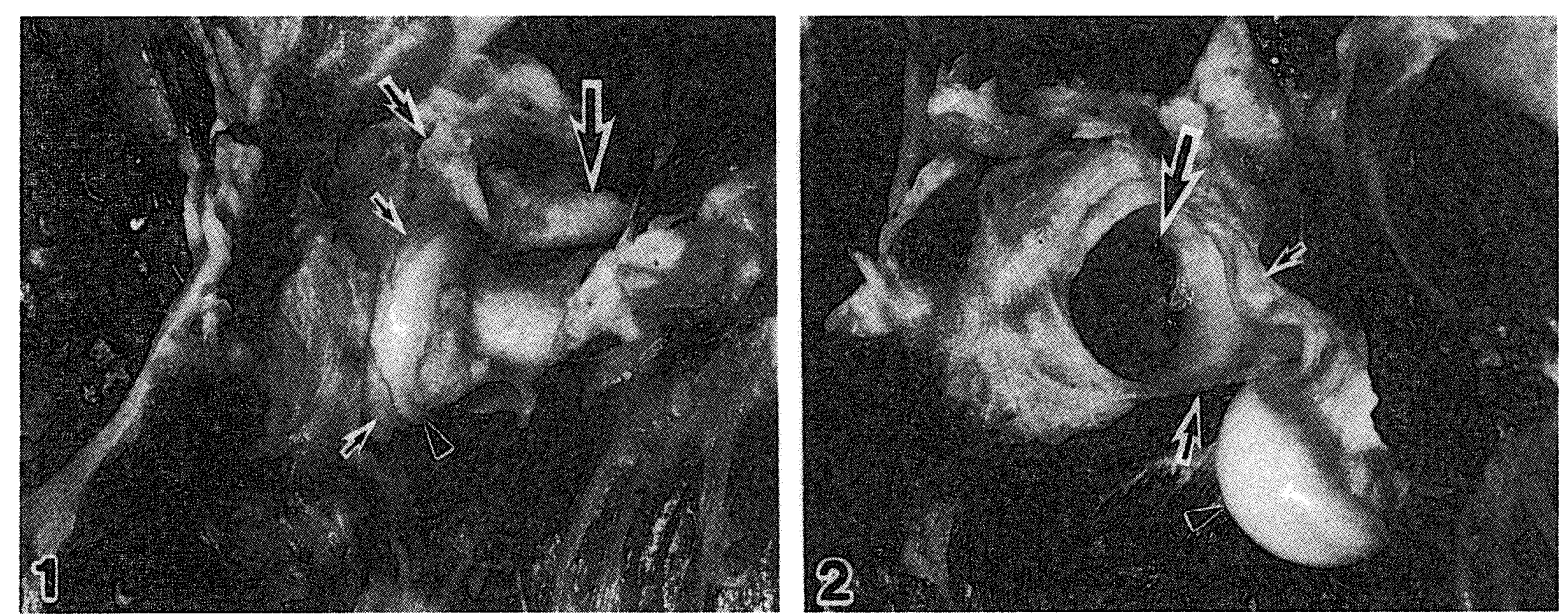

Fig. 1. Hip joint in the adult dead body. Ventro-lateral aspect of the left side. Cranial direction at the top. We observe the slip ends of the lateral (large arrow) and medial (intermediate arrow) parts of the iliofemoral ligament that arise from the neck of the femur. Both parts have been cut near the acetabulum region for the partially dislocation and observation of the head of the femur (arrowhead). The acetabular labrum (small arrows) surrounds the head of femur.

Fig. 2. The similar aspect of the Figure 1. Cranial direction at the top. The head of the femur (arrowhead) has been easily dislocated from the acetabulum. The acetabular fossa (large arrow) is filled with the connective tissues. The thin pubofemoral (intermediate arrow) and thick ischiofemoral (small arrow) ligaments are extended from the pubis and ischium to the neck of the femur and the acetabular labrum, respectively. 


\section{Hip Joint of the Orang-Utan}

In the fetus, the hip joint is shown in the CT sections (Fig. 4). The ossification had already progressed in the shaft area of the femur, the pubis and the ischium, although the head of the femur seemed grayish and had not been ossified. Some weak X-ray absorptions were observed in the space between the head of femur and the acetabulum (Fig. 4), however, the distinctive structure of the ligament of head of the femur could not be encountered.

The CT images helped us to confirm the structure of the hip
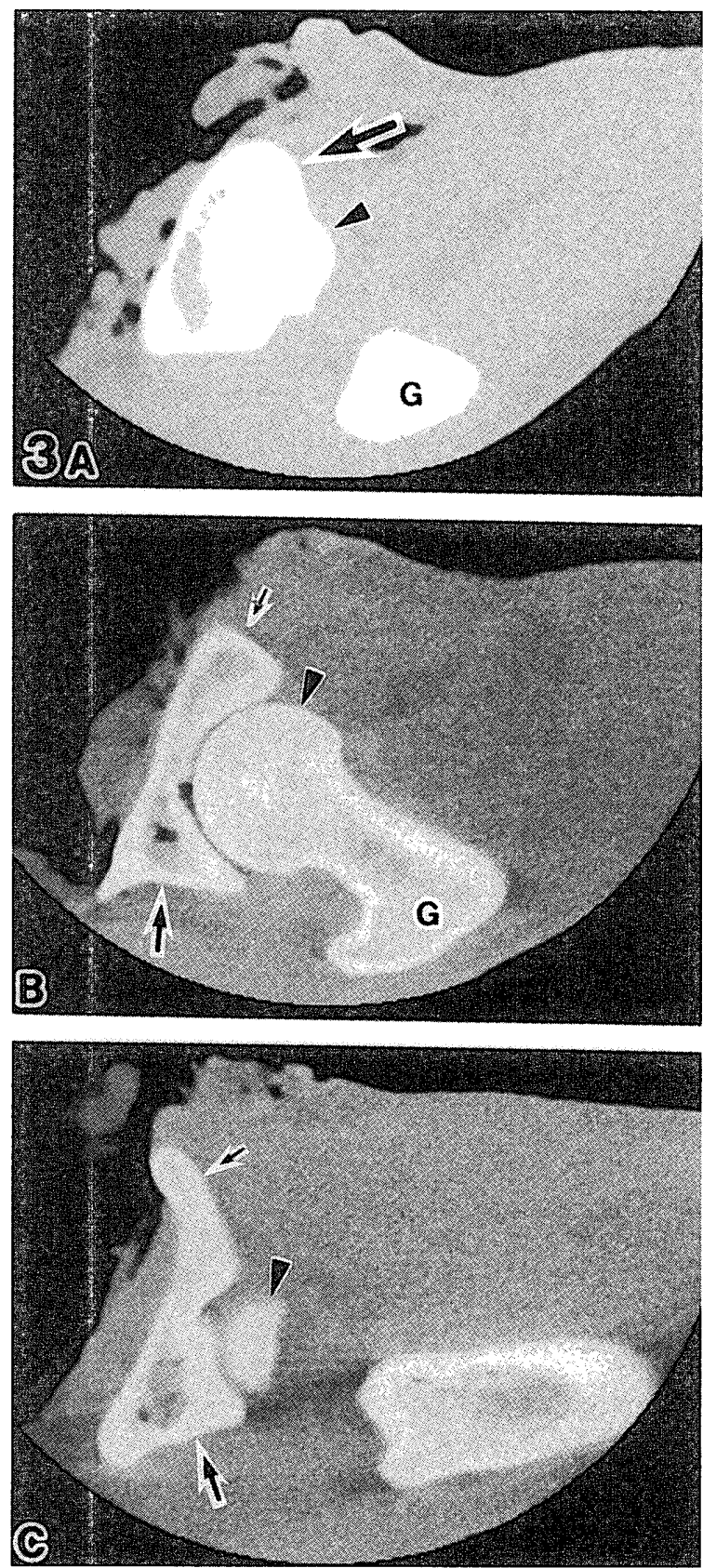

joint as a non-destructive method. The method enabled us to store the rare intact fetus of the orang-utan in the museum. The ligament of the head of the femur already disappeared in this stage of the fetus. However, the CT sectional method is available to observe the disappearance process of its ligament in earlier stage fetus. The head of the femur was delayed in ossification as known in the human in which the ossification progressed in the head of the femur in one year old baby [3]. However, the pattern to bear its body weight using hip bone

Fig. 3. Transverse CT sections of the hip joint in the adult dead body. Right side. Ventral direction at the top. The sections of the cranial (A), intermediate (B), caudal (C) level are arranged. The head of the femur (arrowhead) is located closely in the shallow acetabulum consisted with ilium (large arrow), ischium (intermediate arrow) and pubis (small arrow).

$G$ : the greater trochanter. 


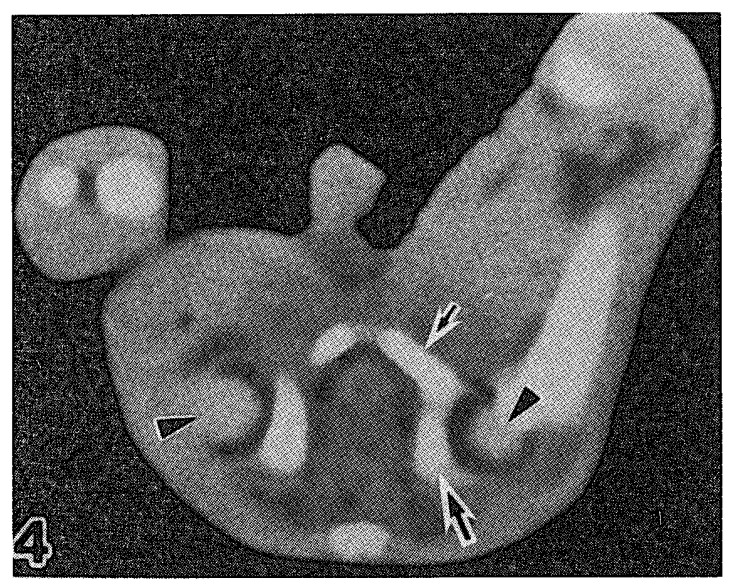

Fig. 4. Transverse CT section of the hip joint in the fetus dead body. Ventral direction at the top. Left side at the right. The head of the femur (arrowheads) are located in the shallow acetabulum consisted with ischium (large arrow) and pubis (small arrow). The ossificating region has progressed strongly absorbs X-rays to appear whitish. The head of the femur has not yet been ossified. The ligament-like structure cannot be seen in the space between the femur head and the acetabulum inner wall.

and the femur in the orang-utan may be obviously different from that in the human. So, in the future, we should detail the ossification pattern in the orang-utan and compare the data with those in the human to clarify the different gravity effect on the ossification between the apes and the human.

As for the function of the hip joint in the orang-utan, the lack of the ligament of head of femur was noteworthy. In the human the ligament of head of femur, the mechanical models of the human have demonstrated that the ligament of head of femur restricted the adduction of the femur [3-8]. The ligament of head of femur prevents the femur from being dislocated during adduction of the thigh. In addition the ligament functions as a restrictor of the extension and flexion of the femur was indicated in the human [6]. These roles are also played by the iliofemoral ligament in the human. Compared with these results in the human, we suggest that the lack of the ligament of head of femur realizes the large mobility of the hip joint in the orang-utan on branches. It enables the orang-utan to largely move the hind limb during its arboreal locomotion. The data also pointed out that the orang-utan showed the shallowest acetabulum in all species of the primates $[1,2,9]$. This shape of the acetabulum and the disappearance of the ligament of head of femur may also help the orang-utan to supplely bend its femur to seize branches or leaves [10]. The report on the thigh muscles demonstrated that Musculus gluteus maximus was well-developed and $M$. gluteus minimus possessed the two main bundles in the orang-utan unlike the other primates [8].
The findings also supported the extraordinary flexibility of the hip joint in the orang-utan as compared with the other apes.

We suggest that the iliofemoral ligament may restrict the adduction and the medial rotation of the femur in the orang-utan. These two functions are substantially similar to those in the human $[3-7,8]$. It was consistent with the findings that the intertrochanteric line was not well-developed as an attachment surface of the ligament in the chimpanzee but observed in both orang-utan and human [1]. While, we thought that this ligament might play an important role in the bipedalism and fix the trunk vertically in the standing posture only in the human [3]. The trunk fixing function may not be so important in the orang-utan as in the human, since the orang-utan is essentially arboreal and does not vertically stand the trunk in its incomplete bipedalism of the terrestrial behavior.

The ligaments of the hip joint have been observed by the CT methods as clinical works in the human $[11,12]$. However, the $\mathrm{CT}$ sections have not been generally examined in the basic anatomy and embryology of the joint ligament and we cannot quantitatively detail the relationships between the CT image and the morphological development of the ligament. From now we should obtain the CT images of the hip joint in the fetus of various mammals to morphologically clarify the development of the ligament of head of femur by non-destructive methods.

\section{ACKNOWLEDGEMENTS}

We thank the staff of Tama Zoological Park for their kind donation of the rare carcasses of the orang-utan and Tomoko Ogoh (National Science Museum, Tokyo) for her encouragement in this study. This study was financially supported by the National Bioresource Projects and the Grant-in-Aids for Scientific Research nos. 13640705 , 13575027, 14405030 and 15570092 from the Ministry of Education, Science and Culture, Japan.

\section{要 約}

オランウータンの成獣と分婏直前の胎子の死体を用いて, 股 関節の構造を CT 断層像で非破壊的に観察し, さらに成獣では 肉眼解剖を行った。CT 画像から, 胎子も成獣同様, 大腿骨頭 勒帯を備えていないことが明らかになった。オランウータンの 大腿骨頭勒带は少なくとも分娩直前の胎子で完全に消失してい ると結論づけることができた。肉眼解剖の結果, 成獣において 腸骨大腿勒帯の 2 つ部位, 貧弱な恥骨大腿勒帯, そしてよく 発達した坐骨大腿勒帯が確認されたが,これまでの報告と合致 して大腿骨頭勒帯は存在しなかった。CT 像は非破壊的に股関 節の構造を確認する上で，有効な方法であると結論できる。 キーワード : CT, 股関節, オランウータン

\section{REFERENCES}

1. Aiello L, Dean C. 1996. Human Evolutionary Anatomy. 4th ed. Academic Press, London.

2. Morebeck EM, Zihlman AL. 1988. Body composition and limb proportions. In Orang-Utan Biology. (Schwartz JH. ed.), pp. 285-297. 
Hip Joint of the Orang-Utan

Oxford Univ. Press, Oxford.

3. Kahle W. Leonhardt H, Platzer W. 1986. Taschenatlas der Anatomie. 5th ed. Georg Thieme, Stuttgart.

4. Benninghoff A. 1985. Makroskopische und Mikroskopische Anatomie des Menschen. Vol. 1. 13rd and 14 th ed. Urban \& Schwarzenberg, München.

5. Fick R. 1911. Handbuch der Anatomie und Mechanik der Gelenke. Fischer, Jena.

6. Fuss FK, Bacher A. 1991. New aspects of the morphology and function of the human hip joint ligaments. Amer J Anat 192: 1-13.

7. Kapandji IA. 1985. Funktionelle Anatomie der Gelenke. Vol. 2. Enke, Stuttgart.

8. Weber W. Weber E. 1836. Mechanik der Menschlichen Gehwerkzeuge. Dieterich, Göttingen
9. Schultz AH. 1969. Observations on the acetabulum of primates. Folia Primatologica 11: 181-199.

10. Ruff R. 1988. Hindlimb articular surface allometry in Hominoidea and Macaca, with comparison to diaphyseal scaling. J Human Evol 17: 687-714.

11. Lafferty CM. Sartoris DJ, Tyson R, Resnick D, Kursunoglu S, Pate D, Sutherland D. 1986. Acetabular alterations in untreated congenital dysplasia of the hip: computed tomography with multiplanar re-formation and three-dimensional analysis. J Comput Assist Tomogr 10: 84-91.

12. Glynn TP Jr, Kreipke DL, de Rosa GP. 1989. Computed tomography arthrography in traumatic hip dislocation. Intra-articular and capsular findings. Skeletal Radiol 18: 29-31. 